\title{
REVITALISASI KEARIFAN LOKAL DALAM PENDIDIKAN DASAR
}

\author{
REVITALIZATION OF LOCAL WISDOM IN EDUCATION
}

\author{
Sularso \\ Prodi PGSD FKIP Universitas Ahmad Dahlan Yogyaakarta \\ Email: sularso@pgsd.uad.ac.id
}

\begin{abstract}
The purpose of this study was to answer the question (1) how to form the revitalization of local knowledge at the level of primary education; (2) why matter local wisdom given to primary education. This study used qualitative methods. The data was obtained from the literature review and observation. Methods of data analysis using qualitative data analysis methods. Researchers examine aspects of basic education and local knowledge are terminological. Both were placed as a single interconnected conceptually. Logical relationship conceptually framed are then analyzed and used to address problems that have been proposed. Results from this research is that the value of local wisdom placed integral with the rest of the learning material. Local wisdom important reason given at the primary level so that learners do not lose the basic cultural values, does not lose its historical roots and has insight and knowledge on social and environmental realities attitude culturally.
\end{abstract}

Keywords: Revitalization, Local Wisdom, Basic Education

\begin{abstract}
Abstrak : Tujuan penelitian ini adalah untuk menjawab persoalan (1) bagaimana wujud revitalisasi kearifan lokal di tingkat pendidikan dasar; (2) mengapa materi kearifan lokal diberikan pada pendidikan tingkat dasar. Penelitian ini menggunakan metode kualitatif. Data diperoleh dari kajian pustaka dan observasi. Metode analisis data menggunakan metode analisis data kualitatif. Peneliti mencermati aspek pendidikan dasar dan kearifan lokal secara terminologis. Keduanya diletakkan sebagai satu kesatuan yang saling terhubung secara konseptual. Hubungan logis yang terbingkai secara konseptual tersebut selanjutnya dianalisis dan digunakan untuk menjawab persoalan yang telah diajukan. Hasil dari penelitian ini adalah bahwa nilai kearifan lokal ditempatkan secara terintegral dengan seluruh materi pembelajaran. Alasan kearifan lokal penting diberikan pada tingkat pendidikan dasar agar peserta didik tidak kehilangan nilai dasar kulturalnya, tidak kehilangan akar sejarahnya serta memiliki wawasan dan pengetahuan atas penyikapan realitas sosial dan lingkungannya secara kultural.
\end{abstract}

Kata Kunci: Revitalisasi, Kearifan Lokal, Pendidikan Dasar

\section{Pendahuluan}

Indonesia adalah negara kepulauan, yang memiliki kekayaan budaya yang beragam. Sebagai negara kepulauan, kehidupan masyarakatnya pun menjadi sangat multikultur. Kesadaran budaya multikultur, tentunya harus sudah tertanam pada diri individu sejak dini agar terhindar dari sikap fatalistic atau chaovenisme. Tujuannya adalah agar konflik sosial yang sering terjadi di tengah-tengah masyarakat dapat diminimalisir dan bahkan teratasi.
Peran pendidikan dasar dalam hal ini menjadi sangat penting, sebagai upaya untuk mencegah munculnya sikap-sikap tersebut sejak dini. Institusi pendidikan — pendidikan dasarsesuai dengan fungsi akademiknya pun harus menangkap potensi keberagaman ini sebagai nilai lebih, sehingga seluruh peserta didik memiliki pemahaman atas keberagaman tersebut. Namun, sebagai nilai lebih acapkali potensi ini kurang mendapatkan perhatian serius. Padahal jika dilihat secara kontekstual di dalam keberagaman terkandung nilai-nilai lokal atau 
kearifan lokal yang dapat dimanfaatkan untuk menjaga keharmonisan sosial maupun keharmonisan alam.

Penelitian ini memandang bahwa kearifan lokal secara substansial mengandung nilai hidup yang termanifestasikan dalam aturanaturan sosial atau pun aturan adat-istiadat, seperti merawat alam, dengan tidak menebang pohon, tidak mengambil air secara berlebihan, dilarang membunuh hewan tertentu, bersikap patuh dan hormat pada orang yang lebih tua, dan lain sebagainya. Hal ini turut ditegaskan Soetomo (2012: 128), melalui proses belajar dan adaptasi pengetahuan dan kearifan lokal juga berfungsi untuk menyesuaikan dan menjaga harmoni dengan lingkungan fisik dan lingkungan alamnya. Bagi Tilaar (2015: 24) kearifan lokal mempunyai nilai pedagogis karena bertujuan untuk mengatur tingkah laku yang bermanfaat bagi kepentingan bersama masyarakat.

Pada tataran konkrit, realitas atas kearifan lokal belum termanifestasikan secara nyata, sehingga institusi pendidikan perlu mewadai potensi kelokalan tersebut menjadi satu materi yang cukup implementatif dan dapat dikontektualisasikan dengan seluruh mata pelajaran yang relevan. Perlunya dilakukan secara implementatif dan konkrit, karena saat ini proses internalisasi atas nilai-nilai kearifan lokal kepada peserta didik khususnya sekolah dasar masih berhenti ditataran konseptual dan belum mewujud pada laku konkrit kehidupan. Padahal menurut Harsya (1985: 17) unsur-unsur budaya selalu hadir dalam setiap interaksi sosial dan bahwa unsur-unsur budaya itu tidak mengambang bebas di udara, melainkan merupakan bagian dari sistem-sistem yang mengakar pada pribadi-pribadi.

Lewat laku konkrit, nilai-nilai kearifan lokal diharapkan dapat tetap hidup dan menghidupi masyarakatnya. Bahkan melalui kearifan lokal dapat menguatkan aspek etika atau moral individu masyarakatnya. Hal ini cukup relevan mengingat masyarakat dalam menyelenggarakan kehidupan tidak dapat terlepas dari pengaruh lingkungan tempat mereka hidup, hubungan timbal balik dan kait mengkait antara nilai filosofis dan cita-cita kolektif masyarakat. Bahkan kondisi sosial masyarakat, kehidupan tradisi, keadaan alam serta latar belakang sejarah pun turut memberikan pengaruh atas sikap dan cara pandang.

Kontekstualisasi pegetahuan atas kearifan lokal sebagai penguatan karakter peserta didik menjadi satu hal yang urgen untuk dilakukan. Hal ini disebabkan globalisasi telah menguasai hajad hidup orang banyak. Apalagi tahun 2016, Indonesia berhadapan dengan komunitas MEA yang cukup kompetitif dan terbuka. Realitas tersebut apabila tidak disikapi secara serius dengan memikirkan langkah strategis, sangat mungkin etnisitas keberagaman kearifan lokal menjadi terdistorsi, terabaikan bahkan dimungkinkan lenyap.

Bukti kearifan lokal yang terabaikan ini terlihat ketika nilai-nilai lokal tidak terserap dan mewujud dalam perilaku kehidupan sehari-hari. Padahal jika kearifan lokal termanifestasikan dalam perilaku atau sikap hidup, identitas masyarakat pemiliknya turut terbentuk. Apalagi karakteristik Indonesia yang multikultur kearifan lokal cukup beragam dan masing-masing memiliki kekhasan. Kenyataan yang terlihat, lokalitas acapkali justru tergerus oleh tatanan gaya hidup yang di dalamnya mengandung nilai pragmatis-kapitalistik. Seperti munculnya pergaulan bebas, penyalahgunaan narkoba, persaingan yang berujung pertikaian, korupsi, tawuran, dan lain sebagainya. Padahal pendidikan dan gaya hidup adalah dua hal yang secara ontologis berlainan. Kasus pembakaran lahan yang terjadi di Sumatera misalnya yang menyebabkan munculnya darurat asap, bencana banjir yang melanda di berbagai daerah, penggunaan pupuk pestisida yang turut memberikan kontribusi atas rusaknya tatanan ekosistem, seluruhnya merupakan satu kenyataan bagaimana kearifan lokal terabaikan.

Pada kasus tersebut, proses pendidikan dengan menjadikan kearifan lokal penting untuk direalisasikan. Hal ini cukup kontekstual apabila digunakan menghadapi persoalan kontemporer saat ini. Pertanyaannya adalah (1) bagaimana wujud revitalisasi kearifan lokal di tingkat pendidikan dasar? (2) mengapa materi kearifan lokal diberikan pada pendidikan tingkat dasar? 
Kedua pertanyaan tersebut menjadi pijakan atas dilakukannya kajian ini, dan diharapkan melalui penelitian ini dapat memberikan simpulan yang bermanfaat bagi pengembangan materi pembelajaran pendidikan dasar dengan menjadikan kearifan lokal sebagai basis eksplorasi pengetahuan.

\section{Metode}

Mengutip pendapat Muhammad Ali dan Muhammad Asrori (2014: 33) dalam konteks riset pendidikan, penelitian ini digolongkan ke dalam jenis riset eksploratoris, yakni riset yang bertujuan untuk menemukan probelmatikproblematik baru dalam dunia pendidikan. Secara fungsional penelitian ini masuk dalam kategori riset dasar. Menurut Muhammad Ali dan Muhammad Asrori (2014: 33), riset dasar dilakukan terutama untuk menemukan pengetahuan baru ataupun teori baru, atau prinsip-prinsip dan generalisasi yang dibutuhkan untuk merumuskan suatu teori, serta dasar pemikiran ilmiah tentang kependidikan. Di samping itu, riset dasar dapat pula dilakukan untuk memahami atau menjelaskan fenomena yang muncul pada suatu hal.

Secara metodologis, penelitian ini menggunakan metode penelitian kualitatif. Data yang digunakan adalah data kualitatif. Ahimsa, (2001: 8) berpendapat, data kualitatif tidak berupa angka tetapi berupa pernyataanpernyataan mengenai isi, sifat, ciri, keadaan, dari sesuatu atau gejala, atau pernyataan mengenai hubungan-hubungan antara sesuatu dengan sesuatu yang lain. Menurutnya, sesuatu ini bisa berupa benda-benda fisik, pola-pola perilaku, atau gagasan-gagasan, nilai-nilai, norma-norma, bisa pula peristiwa-peristiwa yang terjadi dalam suatu masyarakat.

Data diperoleh dari kajian pustaka dan observasi. Data dikategorikan menjadi dua, yakni data mengenai pendidikan dasar, dan kearifan lokal. Pengkategorian data membantu peneliti untuk memahami konsep-konsep dasar. Menurut Anselm Strauss dan Juliet Corbin (2009: 63) pemberian kategori data bertujuan agar peneliti dapat mengingatnya, membahasnya, dan mengembangkannya secara analitik. Adapun kategori data pendidikan dasar digali dari konsep-konsep substasial pendidikan dasar dan orientasi pragmatis dan ideologisnya. Kelompok data kearifan lokal digali dari sudut pandang ontologisnya dan filosofisnya. Pada tahap pengkategorian ini peneliti sekaligus melakukan reduksi data.

Metode analisis data menggunakan metode analisis data kualitatif. Ahimsa, (2001: 8) berpendapat, metode analisis data kualitatif pada dasarnya sangat memerlukan kemampuan untuk menemukan persamaan-persamaan dan perbedaan di antara data kualitatif, dan ini hanya dapat dilakukan apabila konsep-konsep teoritis yang digunakan didefinisikan dengan baik. Pernyataan Ahimsa mendorong peneliti untuk mencermati secara substasial aspek pendidikan dasar dan kearifan lokal secara terminologis. Keduanya diletakkan sebagai satu kesatuan yang saling terhubung secara konseptual. Hubungan logis yang terbingkai secara konseptual tersebut selanjutnya dianalisis dan digunakan untuk menjawab persoalan yang telah diajukan sebelumnya.

\section{Pembahasan}

Sikap membuang hal-hal lama dan segera jemu dengan hal-hal baru merupakan cermin kehidupan masyarakat saat ini. Sikap tersebut dipengaruhi oleh anggapan yang 'lama' kuno atau usang dan tidak relevan lagi untuk digunakan. Cara pandang tersebut hampir jamak, meskipun demikian perlu ada kajian lebih lanjut mengapa 'yang lama' hingga kini dianggap kuno. Tentu, hal ini tidak dapat dibiarkan begitu saja, langkah nyata harus dilakukan institusi pendidikan untuk menjawab fenomena tersebut.

Penelitian ini memandang bahwa sesungguhnya 'yang lama' menyimpan nilai dasar kultural dan berisi sumber daya laten yang urgen untuk diidentifikasi. Hasilnya pun dapat digunakan untuk kepentingan menumbuhkan pendidikan dasar berbasis budaya lokal. Potensi dan sumber daya laten bagi Soetomo (2012: 121) adalah potensi dan sumber daya yang sebetulnya ada dalam masyarakat, namun belum diketahui dan disadarai. Dalam konteks penelitian ini, sumber daya laten yang dimaksud adalah kearifan lokal. 
Kearifan lokal di dalamnya berisi nilai hidup yang lahir dari dalam masyarakat itu sendiri dan digunakan untuk megatur kehidupan sosial. Penggunaan kearifan lokal sebagai materi pembelajaran sesunguhnya bukanlah hal baru. Hal ini dapat dilihat dari catatan sejarah, tatkala Ki Hajara Dewantara aktif menjadi anggota kelompok diskusi budaya, Sarasehan Slasa Kliwonan, dirinya memutuskan untuk mendirikan Sistem Sekolah Nasional yang benarbenar berjiwa bumi putra (Radcliffe, 1987: 207). Pendidikan yang berjiwa bumi putra diartikan sebagai pendidikan yang terbebas dari sistem penjajah Belanda, dan menghasilkan sistem among.

Menurut Radcliffe, (1987: 207), sistem among adalah membangun pendidikan disekeliling anak, dengan secara maksimum memanfaatkan nalurinya untuk mendidik diri. Radcliffe menjelaskan (1987: 207), sistem among juga mengandung arti persatuan hakiki dalam kebudayaan Indonesia. Sebagaimana pendidikan anak, hendaknya didasarkan wataknya yang unik, demikian pula pendidikan bangsa harus dilandaskan pada kebudayaannya yang unik. Gagasan Ki Hajar Dewantara ini menunjukkan bahwa lokalitas memiliki nilai pedagogis yang dapat dimanfaatkan untuk kepentingan pendidikan.

Pengetahuan dan kearifan lokal ini merupakan realitas yang pasti ada dan dimiliki oleh setiap masyarakat. Sifatnya sangat spesifik, serta terbentuk melalui pengalaman dan perjalanan kehidupan masyarakat yang bersangkutan. Bagi Soetomo (2012: 116), setiap masyarakat mempunyai pengalaman kehidupan yang berbeda, maka pengetahuan dan kearifan lokal bentuk dan sifatnya juga bervariasi antarmasyarakat yang berbeda.

Melihat hal tersebut maka, dalam menyelenggarakan pendidikan dasar, pemerintah perlu mengupayakan revitalisasi kearifan lokal sebagai salah satu basis pembentukan identitas dan karakter bangsa dan sebagai salah satu langkah solusi atas persoalan sosial dan atau persoalan alam yang melanda negeri ini. Pemerintah perlu menggunakan konsepsi wawasan nusantara untuk menjawab persoalan tersebut. Melalui konsepsi wawasan nusantara, lokalitas atau kearifan lokal sebagai satu unsur pembentuk jati diri bangsa dan sebagai salah satu langkah solusi atas persoalan sosial dan lingkungan di masing-masing daerah dapat semakin tumbuh.

Penyikapan terhadap realitas persoalan di atas perlu dilakukan, sehingga dapat melahirkan suatu pendidikan kontekstual guna menjawab persoalan tesebut, yakni pendidikan tanpa harus mengabaikan lokalitas sebagai satu nilai lebih. Apabila strategi ini diimplementasikan, dampaknya anak atau peserta didik tidak lagi kehilangan nilai dasar kulturalnya, anak tidak kehilangan akar sejarahnya serta memiliki wawasan pengetahuan atas penyikapan realitas sosial dan lingkungannya. Seluruhnya mewujud pada pandangan hidup. Menurut Tilaar (2015: 38), pandangan hidup berfungsi sebagai pengikat di dalam suatu kehidupan sosial. Adapun penelitian ini memahami bahwa pandangan hidup cukup memberikan pengaruh atas terbentuknya tingkah laku manusia di dalam hidupnya sehari-hari.

Nilai dasar kultural yang tercermin dalam pandangan hidup menjadi satu hal yang penting. Mereka dapat menggali pengetahuan atau wawasan tanpa harus tercerabut dari rahim budayanya. Tatkala, peserta didik yang sedang menempuh pendidikan dasar dan mendapatkan pengetahuan mengenai pemanfaatan pandangan hidup berbasis kearifan lokal, maka sangat mungkin dirinya tak lagi terasing oleh lingkungan budayanya.

Tersampaikannya pandangan hidup yang bersumber dari kearifan lokal, membuat peserta didik tidak lagi inverior terhadap pandangan ala Barat yang secara kontekstual seluruhnya belum tentu relevan dengan karakter dan jati diri bangsa. Di sinilah letak pentingnya kearaifan lokal dibangun sejak dini di lingkungan pendidikan dasar. Mengingat pada tahap ini elemen-elemen dasar kultural yang ada di dalam kearifan lokal disemayamkan pada diri peserta didik.

Tilaar (2015: 65), berpendapat pandangan hidup -weltanschauung- yang sedang dibentuk oleh bangsa Indonesia haruslah 
dibangun dari masing-masing pribadi anggota masyarakat bangsa Indonesia. Padangan Tilaar menegaskan betapa pentingnya pandangan hidup bangsa itu dibangun dari akar budaya masyarakatnya. Pandangan Tilaar menghantarkan penelitian ini pada satu pemahaman bahwa kearifan lokal dalam perspektif pendidikan menjadi modal dasar bagi proses pertumbuhan pendidikan yang berbasis pada nilai budaya lokal. Adapun cara memperlakukan kearifan lokal dalam pendidikan dasar adalah dengan menempatkan nilai kelokalan secara terintegral dengan seluruh materi pembelajaran sehingga nilainya benarbenar hidup.

Secara lebih luas, pertumbuhan nilai ini harus dibarengi dengan langkah nyata yang termanifestasikan dalam perilaku hidup keseharian. Artinya kearifan lokal bukan saja diletakkan pada konteks muatan lokal yang sering dijumpai pada kurikulum pedidikan yang terkesan marginal, dan miskin realisasi. Namun harus sudah implementatif, konkrit dan menyeluruh atau terintegrasi dengan mata pelejaran lain. Pada tahap ini nilai-nilai kearifan lokal harus sudah teridentifikasi dan sudah dapat dirumuskan, yang hasilnya dapat segera diimplementasikan.

Perlu ditekankan bahwa dalam konteks ini penekanannya pada sikap atau perilaku, bukan hanya pada aspek kognitif saja. Kearifan lokal diarahkan pada 'positif disiplin' seperti yang dinyatakan Anis Baswedan dalam harian Kompas di Kolom Edukasi tanggal 12 Desember 2015. Anis mencontohkan makna positif disiplin adalah mengupayakan suatu kondisi di mana seseorang yang mengalami kegagalan terpacu untuk menjadi lebih baik lagi (Kompas, 12 Desember 2015). Makna bangkit dari kegagalan diartikan sebagai satu kondisi peserta didik untuk dapat memunculkan modus vivendi —cara hidup - berdasarkan pada nilai-nilai kearifan lokal yang telah diresapi. Pada kasus kegagalan ini peserta didik didorong untuk melakukan proses belajar dan adaptasi dengan mendasarkan pada nilai-nilai kelokalan yang mereka konstruksi sendiri.
Pada sisi lain, nilai kebersamaan sebagai respon penanggulangan atas kegagalan juga dapat ditumbuhkan dari penggalian kearifan lokal. Seperti pendapat Soetomo (2012: 116), kearifan lokal dapat menyeleksi agar kepentingan bersama berada di atas kepentingan kelompok apalagi kepentinga individu dalam setiap tindakan bersama. Pada level kebijakan, sikap adaptif pemerintah terhadap potensi kearifan lokal sudah tampak, dan telah diwujudkan dalam mata pelajara muatan lokal. Namun persoalan yang terjadi sampai saat ini belum dapat menjawab krisis identitas, krisis sikap, dan krisis 'cara pandang dalam'. Padahal idealnya menurut Colletta (1987: 26) masalahmasalah pembangunan dan pemecahannya harus bersumber dari masyarakat itu sendiri sehingga pemecahan tersebut sungguh-sungguh kena dan bukan bersifat tambal sulam.

Revitalisasi kearifan lokal dalam perspektif pendidikan dasar dengan demikian menjadi sangat penting, bahkan harus mendapat prioritas. Bagi Colletta, (1987: 26), lembagalembaga luar harus membantu masyarakat setempat - peserta didik- untuk mencari pemecahan dari dalam masyarakat itu sendiri sehingga sumber-sumber daya yang ada dalam masyarakat tersebut dapat dikerahkan. Pengerahan sumber daya lokal merupakan sarana yang efektif untuk disampaikan kepada peserta didik secara praktis. Melalui cara ini peserta didik dapat menghayati dan mengimplementasikan kandungan kearifan lokal melalui proses belajar secara langsung. Lebih jauh, peserta didik memiliki kemampuan dan keterampilan dalam mengidentifikasi dan mendayagunakan potensi kultural yang dimiliki.

Alasan pentingnya revitalisasi kearifan lokal di tingkat pendidikan dasar di antaranya (1) terjaganya identitas budaya di masing-masing daerah secara terstrukut melalui pendidikan dasar; (2) terpetakannya keberagaman nilai pendidikan berbasis kearifan lokal sehingga dapat digunakan untuk menyusun kebijakan pendidikan dasar multi budaya; (3) mengajarkan peserta didik untuk mengerti makna keberagaman secara elementer. 
Bagi Soetomo (2012: 124), kearifan lokal dapat digunakan untuk menjaga keseimbangan dan keselarasan hubungan internal dan eksternal. Secara internal, kearifan lokal dapat menjadi perekat kohesi sosial yang dalam banyak kesempatan mempunyai potensi merenggang sejalan dengan perubahan kondisi kehidupan sosial ekonomi. Secara eksternal, kearifan lokal berfungsi mengendalikan eksklusivitas lokal yang justru dapat merugikan perkembangan masyarakat sendiri.

Adapun unsur-unsur yang terkandung di dalam kearifan lokal menurut Soetomo (2012: 124) adalah nilai keterbukaan, toleransi dalam rangka berhubungan dengan pihak ekternal. Unsur inilah yang dapat menjadi modal penting bagi peserta didik untuk membangun komunikasi antar budaya. Analisis di atas memberikan satu benang merah bahwa manfaat revitalisasi kearifan lokal pada tataran praktis telah menyentuh tiga kompetensi, yakni kompetensi pedagogis, sosial dan kepribadian. Ketiga kompetensi ini menjadi sarana pemenuhan ketercapaian pendidikan bagi seluruh peserta didik, sehingga fenomena kearifan lokal memiliki peran strategis guna mengatasi persoalan yang bersifat multidimensional.

\section{Simpulan}

Kearifan lokal adalah kekayaan yang dimiliki oleh bangsa Indonesia. Menjaganya tentu bukanlah hal yang mudah, mengingat di tengah komunitas ASEAN, Indonesia menjadi bagian dari sistem globalisasi. Efek globalisasi secara negatif menimbulkan homogenisasi dan melemahnya budaya lokal, munculnya hibridisasi budaya karena terjadinya pertemuan antara budaya lokal dan budaya global, dan yang paling ekstrem adalah timbulnya konflik budaya.

Nilai positif dari keberagaman ini adalah kekayaan kearifan lokal. Pendidikan mengenai kearifan lokal menjadi penting karena untuk menjaga kebhinekaan dan potensi kearifan lokal agar tidak tergerus oleh gaya hidup modern. Penelitian ini menyimpulkan bahwa upaya menggali, menanam, dan menyemai potensi kearifan lokal merupakan usaha untuk kembali pada nilai khasanah kearifan lokal sebagai bagian dari upaya membangun identitas dan karater peserta didik berbasis budaya. Cara yang dilakukan adalah dengan mengidentifikasi kearifan lokal terlebih dahulu selanjutnya merumuskannya secara terstruktur. Hasilnya selanjutnya disampaikan kepada peserta didik secara langsung, yakni dengan menempatkan nilai kearifan lokal secara terintegral dengan seluruh materi pembelajaran. Tujuannya agar nilai-nilai kearifan lokal benar-benar hidup.

Alasan mengapa materi kearifan lokal penting diberikan pada tingkat pendidikan dasar agar peserta didik tidak lagi kehilangan nilai dasar kulturalnya, tidak kehilangan akar sejarahnya serta memiliki wawasan dan pengetahuan atas penyikapan realitas sosial dan lingkungannya secara kultural. Pemberian di tingkat pendidikan dasar karena tahap ini merupakan tahap paling awal dan cukup kontekstual untuk mendasari peserta didik sebelum mengenyam pendidikan yang lebih tinggi. Alasan kontekstual lainnya adalah untuk membangun kerinduan pada kehidupan nenek moyang, yang menjadi tonggak kehidupan masa sekarang. Selain itu sebagai jembatan yang menghubungkan antara masa lalu dan masa sekarang, antara generasi nenek moyang dan generasi sekarang, yang hasilnya dapat diarahkan untuk menyiapkan masa depan dan generasi mendatang agar memiliki kesadaran budaya dan kesadaran sejarah budayanya.

Dengan demikian wawasan lokalitas perlu disemai sejak dini, dengan tetap menedepankan pendekatan multikultur. Wawasan lokalitas dengan perspektif multikultur ini menghendaki terciptanya persatuan dan kesatuan dengan tidak menghilangkan ciri, sifat dan karakter dari kebhinekaan di masing-masinh daerah.

\section{DAFTAR PUSTAKA}

Ahimsa-Putra, Heddy Shri. "Paradigma, Epistemologi dan Etnografi dalam Antropologi”. Makalah disampaikan dalam ceramah "Perkembangan Teori dan Metode Antropologi", diselenggarakan oleh Departemen 
Antropologi, Fakultas Ilmu Sosial dan Ilmu Politik, Universitas Airlangga, di Surabaya, 6-7 Mei 2011.

Bachtiar, Harsya. W. 1985. "Konsesnsus dan Konflik dalam Sistem Budaya di Indonesia", dalam Harsya. W. Bachtiar, Mattulada, Haryati Soebadio. Budaya dan Manusia Indonesia. Yogyakarta: Hanindita.

Colletta, Nat. J. dan Umar Kayam. 1987. Kebudayaan dan Pembangunan, Sebuah Pendekatan Terhadap Antropologi Terapan di Indonesia. Jakarta: Yayasan Obor Indonesia.

Radcliffe, David. 1987. "Ki Hajar Dewantara dan Sekolah Taman Siswa: Catatan Mengenai Teori Pendidikan di Luar Sistem Penjajahan" dalam Colletta, Nat. J. dan Umar Kayam. Kebudayaan dan Pembangunan, Sebuah Pendekatan Terhadap Antropologi Terapan di Indonesia. Jakarta: Yayasan Obor Indonesia.
Soetomo. 2012. Keswadayaan Masyarakat, Manifestasi Kapasitas Masyarakat untuk Berkembang secara Mandiri. Yogyakarta: Pustaka Pelajar.

Strauss, Anselm dan Corbin, Juliet. Dasar-dasar Penelitian Kualitatif, Tatalangkah dan Teknik-teknik Teoritisasi Data. Yogyakarta: Pustaka Pelajar.

Tilaar, H.A.R. 2015. Pedagogik Teoritis untuk Indonesia. Jakarta: Buku Kompas. 